\title{
INSTITUTIONAL ANALYSIS OF REVOLVING FUND LOAN (RFL) FOR THE DEVELOPMENT OF COMMUNITY FOREST PLANTATIONS (CFP)
}

\author{
Entin Hendartin ${ }^{1,2}$, Bramasto Nugroho ${ }^{3}$, Hariadi Kartodihardjo ${ }^{3}$ and \\ Dudung Darusman ${ }^{3}$
}

\begin{abstract}
The purpose of this study was to formulate effective and efficient institutions of Revolving Fund Loans for Community Forest Plantation development (RFL CFP) in accordance with variation of field conditions. Benchmarking techniques were used to formulate the institution of RFL CFP. For that purpose, Independent of Direct Assistance Rural Agribusiness Development (IDA RAD) from the Ministry of Agriculture was selected as a benchmark as it was good in performance. The study was conducted in three provinces, i.e. Riau, South Kalimantan (November 2008 to April 2009) and West Java (May 2009 to February 2011). Comparative study was used to analyze the institutions based on the agency theory. The results showed that the institutional of RFL CFP havenot accomodated the differences in characteristics, perceptions and capacities of the parties. As a result, the institutions have not been able to overcome the risk of moral hazard, adverse selection and high transaction costs. On the other hand, the institution of IDA RAD has a positive impact on agency relationship. High repayments by IDA RAD agent and the increasing number of agents each year have proved the impact.
\end{abstract}

Keywords: Institutional, relationship, revolving loan fund, community Forest Plantation, CDARAD

\section{INTRODUCTION}

In 2007, the MoF (Ministry of Forestry) cq Ditjen BPK (Directorate General of Forest Production Development) has initiated the Revolving Fund Loan for Community Forest Plantations (RFL CFP). The program was established through Regulation of the Minister of Forestry No P.48/Menhut-II/2007 jo regulation of the Minister of Forestry no P.64/Men-Hut-II/2009 related to standard cost of IFP (Industrial Forest Plantations) and CFP (Coomunity Forest Plantations), and the regulation of the Minister of Forestry No P.9/Menhut-II/2008 in March $24^{\text {th }}, 2008$ regarding the requirements for Farmer Groups to obtain the RFL CFP.

Up to August 2011 the disbursement of the RFL CFP has reached $0.0035 \%$ of the set target. This performance may have reflected the institutional forms that govern the relationship beetween the principal (RFL CFP lender especially PSA CFDF (Public

\footnotetext{
Graduate School, Bogor Agricultural University

${ }^{2}$ Corresponding author: hendartin@yahoo.com

${ }^{2}$ Departement of Forest Management, Faculty of Forestry, Bogor Agricultural University
} 
Service Agency - Center for Forest Development Funding) from the Ministry of Forestry) and the agents (RFL CFP recipients, especially farmers). The RFL CFP Institutions (such as organizations and rules of the game) are the institutions that regulate the relationship between principal and the agent or often called the agency relationship (Jensen and Meckling, 1986; Eisenhardt, 1989; Prihadi, 2010) suspected to have an influence on performance in the principal agent relationship (Maskin, 2001; Gibbons, 2005; Prihadi and Nugroho, 2007; Prihadi, 2010). The following problems are likely to be found: (1) wrong selection of partners (adverse selection risk) before credit agreement (ex ante) and (2) irresponsible mentallity or untrustworthiness (moral hazard) after the credit agreement (ex post). The phenomena mentioned above have raised questions of the research as follows: (1) whether the caracteristics of the farmers or candidate agents are well known by the principal, and (2) whether the institutions of RFL CFP are able to overcome adverse selection and moral hazard.

Based on the above explanation, this study is aimed to formulate efective and efficient loan institutions for the CFP development that fit to varying field conditions. The specific objectives are: (1) to know the process of policy development regarding the RFL CFP, (2) to understand the organizational form of the PSA CFDF as fund management of the RFL CFP, and (3) to know the characteristics and perceptions of stakeholders on the RFL CFP.

To achievethe research goals, it is necessary to have a succesfull credit agency as a model. CDA RAD (Community Direct Aids of Rural Agribusiness Development) from the Ministry of Agriculture was selected as a model due to the following reasons: (1) Credits provided by the MoF such as KUK DAS (Watershed Conservation Business Credit) and KUHR (Community Forest Business Credit) were considered unsuccessful (MoF, 2005), (2) CDA RAD is able to increase the initial capital from 25 to $250 \%$ in which the fund management is done by FGA (Farmers Group Association or GAPOKTAN), and (3) the number of farmers whose CDA RAD beneficiaries is continuously increase.

\section{RESEARCH METHODS}

\section{A. Study Site and General Information}

The research was conducted in three provinces: (1) Riau (Kuansing District), (2) South Kalimantan (Tanah Laut District), on November 2008 until April 2009, and (3) West Java (Bogor District), on Mei 2009 until February 2011. Selection of the study sites was conducted through rapid appraisal activities throughout Indonesia and preliminary survey through interviews to the key informants and head of the households. Kuansing and Tanah Laut Districts were selected due to some reasons: (1) wood processing industries, such as wood working and pulp industries are exist, (2) competition of land use between palm oil crops and timber plantations, (3two kinds of timber plantations 
are present in the study sites, classified as fast growing species (mangium and kadam) and slow growing species (mahogany), (4) the two provinces were selected by MoF as the location for Community Forest Plantations, and (5) there are active farmers cultivating timber plantations.

Interviews and questionnaires to microcredit stakeholders were carried out by purposive method. The total number of informants was 355 people including farmers, representatives from MoF and working units of the province and district levels, representatives from formal and non-formal financial institutions, academicians, researchers, extension officers (BP3K - agriculture, fisheries and forestry extension center at the sub-district level), BP4K (extension implementing agency for agriculture, fisheries and forestry at district level) and the company's representatives. A detail informants can be seen in Table 1 .

Table 1. Detailes of informants

\begin{tabular}{|c|c|c|c|}
\hline Study site & Activities & Informants & $\begin{array}{c}\text { Total } \\
\text { (Person) }\end{array}$ \\
\hline \multirow[t]{2}{*}{ Riau } & $\begin{array}{l}\text { Open and Closed } \\
\text { interview }\end{array}$ & Farmers & 103 \\
\hline & $\begin{array}{l}\text { FGD, and Open and } \\
\text { Closed interview }\end{array}$ & $\begin{array}{l}\text { Stakeholders except } \\
\text { Farmers }\end{array}$ & 21 \\
\hline \multirow[t]{2}{*}{ South Kalimantan } & $\begin{array}{l}\text { Open and Closed } \\
\text { interview }\end{array}$ & Farmers & 153 \\
\hline & $\begin{array}{l}\text { FGD, Open and } \\
\text { Closed interview }\end{array}$ & $\begin{array}{l}\text { Stakeholders except } \\
\text { Farmers }\end{array}$ & 18 \\
\hline West Java & $\begin{array}{l}\text { Open and Closed } \\
\text { interview }\end{array}$ & Farmers & 27 \\
\hline $\begin{array}{l}\text { Ministy of } \\
\text { Agriculture }\end{array}$ & $\begin{array}{l}\text { Open and Closed } \\
\text { interview }\end{array}$ & $\begin{array}{l}\text { Stakeholders except } \\
\text { Farmers }\end{array}$ & 8 \\
\hline $\begin{array}{l}\text { Ministry of } \\
\text { Forestry }\end{array}$ & $\begin{array}{l}\text { Open and Closed } \\
\text { interview }\end{array}$ & Head and Staffs & 17 \\
\hline Expert & $\begin{array}{l}\text { Open and Closed } \\
\text { interview }\end{array}$ & $\begin{array}{l}\text { Academicians, researchers, } \\
\text { bureaucrats }\end{array}$ & 8 \\
\hline Total & & & 355 \\
\hline
\end{tabular}




\section{B. Data Analysis}

Two types of data (primary and secondary) were collected. Method of primary ${ }^{1}$ data collection is done through recording, observation, interviews (open and closed questions), and FGD 2 (Focus Group Discussion). Secondary data was collected through study of literatures such as regulations and decisions of policy makers related to the RFL CFP. The methods of data analysis consisted of: (A) Content analysis (Bungin, 2007) and analysis of policy space (IDS, 2006) and agency relationship (Jensen and Meckling, 1986; Eisenhardt, 1989; Prihadi, 2010), (B) Comparative institutional analysis (Hirakuri, 2003), (C) Agency relationship (Jensen and Meckling, 1986), and (D) Descriptive analysis (Bungin, 2007) and Analytical Hierarchy Process/AHP (Saaty, 2003). Further details of the methods are shown in Table 2.

Table 2. Methods of data analysis applied in the study

\begin{tabular}{|c|c|c|c|}
\hline Variable & Indicator & $\begin{array}{l}\text { Colection Data } \\
\text { Method }\end{array}$ & $\begin{array}{l}\text { Analysis Data } \\
\text { Method }\end{array}$ \\
\hline $\begin{array}{l}\text { Policy Process } \\
\text { Formulation }\end{array}$ & $\begin{array}{l}\text { All the rules that regulate } \\
\text { relationship between } \\
\text { principle and agent }\end{array}$ & $\begin{array}{l}\text { Primary and } \\
\text { secondary } \\
\text { Document, } \\
\text { interviews, FGD }\end{array}$ & $\begin{array}{l}\text { Content analysis } \\
\text { (Bungin, 2007; } \\
\text { Irawan, 2007), policy } \\
\text { space analysis (IDS, } \\
\text { 2006), and agency } \\
\text { relationship (Jensen } \\
\text { and Meckling, 1986; } \\
\text { Prihadi, 2010) }\end{array}$ \\
\hline Organizations & $\begin{array}{l}\text { Vision or Goals, human } \\
\text { resources, infrastructure, } \\
\text { authority related contract }\end{array}$ & $\begin{array}{l}\text { Secondary data, } \\
\text { interviews, FGD }\end{array}$ & $\begin{array}{l}\text { Open and closed } \\
\text { interviews, literature } \\
\text { study, comparative } \\
\text { institutional analysis } \\
\text { (Hirakuri, 2003) }\end{array}$ \\
\hline $\begin{array}{l}\text { Characteristics } \\
\text { and percep- } \\
\text { tions of the } \\
\text { stakeholders }\end{array}$ & $\begin{array}{l}\text { Farmer characteristic, } \\
\text { marketing situatio n, market } \\
\text { access, farmer behavior on } \\
\text { credit, farmer perceptions } \\
\text { toward RFL CFP and CDA } \\
\text { RAD, perceptions of } \\
\text { stakeholders (except for } \\
\text { farmers) toward RFL CFP } \\
\text { and CDA RAD }\end{array}$ & $\begin{array}{l}\text { observations, open } \\
\text { and closed } \\
\text { interviews, FGD }\end{array}$ & $\begin{array}{l}\text { Agency relationship } \\
\text { (Jensen and } \\
\text { Meckling, 1986) }\end{array}$ \\
\hline
\end{tabular}

\footnotetext{
${ }^{1}$ Some of the primary data, especially in the province of Riau and South Kalimantan obtained from the retrieval data that has been done by a team from several institutions such as CIFOR, IPB and Research Institutions in the two provinces.

${ }^{2}$ Focus Groups Discussion (FGD) according to Bungin (2007) is a data collection technique which is generally done in qualitative research, the goal is to find the meaning of a theme in the opinion or understanding of a group. FGD is intended to avoid a wrong interpretation of the researcher related to the focus on the problem being studied.
} 


\section{RESULTS AND DISCUSSION}

\section{A. Principal Agent Relationship in the Regulations and Decisions on RFL CFP}

The process of formulating regulations and decisions on the RFL CFP involves the following facts: (1) The program was launched in haste. Essentially it was political response from $\mathrm{MoF}$ to the three development policy pillars from the Indonesian United Cabinet namely: pro poor, pro job and pro growth, (2) Annual and five year targets of the RFL CFP were determined only by calculation on the paper without support of an in-depth research, (3) Insufficient capacity and capability of the parties that have been understood by MoF, and the implications for rules are complicated as a form of high prudence of MoF [29 steps to obtain IUPHHK HTR (Business licence for timber utilzation CFP), 30 stages to get the RFL CFP, and involves 10 organizations], (4) Increased capacity and capability of the parties planned to be carried out gradually after the RFL CFP was launched, and (5) If the capacity and capabilities of the parties has increased, the RFL CFP rules will be changed to a simpler form (the head of PSA CFDF personal communication).

Understanding on how RFL CFP policy formulated is very important as learning material to improve the relationship between principal and agent and the RFL CFP performance. Policy formulation process is not an easy process, especially when the opportunity is not available. Narration, actor or network, political interest and information or knowledge is presented in Table 3.

Table 3. Policy Space of the RFL CFP

\begin{tabular}{ll}
\hline Analysis & RFL CFP Policy Formulation Process \\
\hline Discourse/ & MoF considers that farmers need financial support for the CFP so that \\
Narrative & $\begin{array}{l}\text { the funding agencies such as the Bank without collateral requirements are } \\
\text { needed (embodied in the form of PSA CFDF because farmers are not } \\
\text { bankable). } \\
\text { RFL CFP single scheme was created based on consideration to ease of } \\
\text { adminstration by the principal this condition illustrates that the capacity } \\
\text { of principal has not been sufficient and the aspiration of the agent has not } \\
\text { been taken into account }\end{array}$ \\
Contributions of the parties is minor \\
Pctor/network & $\begin{array}{l}\text { RFL CFP is a form of financial support at the discretion of CFP. The use } \\
\text { of Reforestation Fund was regulated in the Government Regulation ( PP }\end{array}$ \\
Information/ & 35/ 2002) concerning reforestation fund article 12, paragraph 3) \\
Rnowledge &
\end{tabular}

Source: IDS (2006), Description: the results of data analysis 
The policy process formulation of the RFL CFP supported by researchers and practitioners is limited to the minimum area that can be managed by farmers and can provide a decent profit. The financing schemes that are based on the standard of field cost of the HPHTI (industrial forest concession) holders are incompatible with Lackey (2007) in Kartodihardjo (2008) who stated that "the application of policy in the field requiring repaired framework that enables knowledge and information can be properly adopted”.

\section{B. PSA CFDF Organization as a Fund Manager of the RFL CFP}

PSA CFDF is the organization within the MoF which functions to manage the RFL CFP and is based only in Jakarta. Constraints faced by the PSA CFDF are it has limited authority as not all decisions can be made internally and may need to refer to the regulations applied in the other ministries (e.g. Ministry of Finance, Ministry of State for Official Administration and Bureauchracy Reformation). Thereby, the PSA CFDF as principal has limited authority, i.e. it is not able to: (1) Control organizational change and establish priorities, (2) Improve its own capacity and capabilities, (3) Determine the procedures for implementing different tasks effectively and efficiently, (4) Impose power to organizations regardless the structural level nor different ministries because it has not command line.

Institution differencess (organization and rules of the game) between the RFL CFP and the CDA RAD will be presented at Table 4.

Table 4. Institutional comparison between RFL, CFP and CDA RAD

\begin{tabular}{|c|c|c|}
\hline Aspects & RFL CFP & CDA RAD \\
\hline \multicolumn{3}{|l|}{ Situation } \\
\hline Purpose & $\begin{array}{l}\text { Improving the welfare of farmers } \\
\text { around the forest }\end{array}$ & $\begin{array}{l}\text { Improving the welfare of farmers } \\
\text { around the forest }\end{array}$ \\
\hline Human resources & Low capacity and varied & Higher capacity and equal level \\
\hline $\begin{array}{l}\text { Location of office } \\
\text { Structure }\end{array}$ & in Jakarta & in every village \\
\hline \multicolumn{3}{|c|}{ Insitutional characteristics } \\
\hline Property right & Government owned & Privately owned \\
\hline $\begin{array}{l}\text { Jurisdiction } \\
\text { boundary }\end{array}$ & low & High \\
\hline $\begin{array}{l}\text { Rules of the } \\
\text { representative } \\
\text { contract }\end{array}$ & $\begin{array}{l}\text { Representation is not running (Top } \\
\text { down) }\end{array}$ & Bottom up \\
\hline Procedure & $\begin{array}{l}\text { Long (included } 30 \text { steps and } 10 \\
\text { organizations to get the RFL CFP) }\end{array}$ & $\begin{array}{l}\text { Short (farmers came to GFA/PFI } \\
\text { office in his village) }\end{array}$ \\
\hline $\begin{array}{l}\text { Signing the } \\
\text { contract }\end{array}$ & $\begin{array}{l}\text { Head of PSA CFDF (Prin cipal) and } \\
\text { head of farmer groups as agents }\end{array}$ & $\begin{array}{l}\text { Head of GFA/PFI (public } \\
\text { financial institutions) and } \\
\text { treasurer as principal, farmer as } \\
\text { agent }\end{array}$ \\
\hline
\end{tabular}


Table 4. Continued

\begin{tabular}{|c|c|c|}
\hline Aspects & RFL CFP & CDA RAD \\
\hline $\begin{array}{l}\text { Control over } \\
\text { contracts }\end{array}$ & PSA CFDF, high transaction cost & GFA/PFI, low transactions cost \\
\hline Financing scheme & $\begin{array}{l}\text { single }\left(\operatorname{Rp~} 8,531,900 \mathrm{ha}^{-1}\right), \text { min area } 8 \\
\text { ha }\end{array}$ & $\begin{array}{l}\text { Depends on farmers need } \\
\text { (agriculture, livestock, and trade) }\end{array}$ \\
\hline $\begin{array}{l}\text { RFL CFP } \\
\text { Distrbution }\end{array}$ & $\begin{array}{l}\text { PSA CFDF (executing), transfer } \\
\text { through BRI }\end{array}$ & $\mathrm{PFI}^{*}$ formed by GFA \\
\hline RFL CFP refunds & PSA CFDF through BRI & PFI GFA \\
\hline $\begin{array}{l}\text { Breach of } \\
\text { contract }\end{array}$ & $\begin{array}{l}\text { Handed over to the applicable law } \\
\text { (police, prosecutors) }\end{array}$ & PFI GFA and social sanctions \\
\hline \multicolumn{3}{|l|}{ Behaviour } \\
\hline Training & Adequate but uneven & Fairly and evenly \\
\hline Credit agreement & $\begin{array}{l}\text { Head of PSA CFDF, treasure and } \\
\text { head of farmer groups }\end{array}$ & $\begin{array}{l}\text { Head of GFA/PFI, treasure } r \text {, and } \\
\text { farmers }\end{array}$ \\
\hline $\begin{array}{l}\text { Agent reports } \\
\text { (physical and } \\
\text { finacial) }\end{array}$ & exist & none \\
\hline Cost recovery & $\begin{array}{l}\text { Operating costs come from APBN } \\
\text { (the state income and expenditure), } \\
\text { the RFL CFP from refo restation } \\
\text { fund, the RFL CFP interest goes into } \\
\text { the forest development account (the } \\
\text { state treasury) }\end{array}$ & $\begin{array}{l}\text { Operational costs from the loan } \\
\text { service }\end{array}$ \\
\hline \multicolumn{3}{|l|}{ Performance } \\
\hline Adverse selection & $\begin{array}{l}\text { High, as human resources are not } \\
\text { sufficient }\end{array}$ & $\begin{array}{l}\text { Low because princip al have } \\
\text { sufficient human resources }\end{array}$ \\
\hline Moral hazard & $\begin{array}{l}\text { Moral hazard is high because the } \\
\text { principal and agent are apart, } \\
\text { asymmetric information, social } \\
\text { sanction is not running }\end{array}$ & $\begin{array}{l}\text { Moral hazard is lower because the } \\
\text { principle and agent near, } \\
\text { symmetric information, social } \\
\text { sanction is running }\end{array}$ \\
\hline Information & asymmetric & Symmetric \\
\hline Transaction cost & $\begin{array}{l}\text { High because of distance and long } \\
\text { procedure (high transaction cost) }\end{array}$ & $\begin{array}{l}\text { Lower because of distance is near } \\
\text { and short procedur (high } \\
\text { transaction cost is lower) }\end{array}$ \\
\hline
\end{tabular}

Description: the primary data processing is displayed using a table model Hirakuri (2003)

From Tabel 4 it is known that the RFL CFP (covering the situation, structure, organization, and behavior) has contributed to the increase in transaction cost, moral hazard and adverse selection. 


\section{Characteristics of Farmers, Markets and Perceptions of the Parties toward the RFL CFP}

\section{- Characteristics offarmers and markets}

At present, the characteristics of farmers including the social system (social sanctions and rules of the game) have not been taken into consideration by policy makers of the RFL CFP as one of the factors that will influence the success of the RFL $\mathrm{CFP}$, whereas characteristics such as age, education, group abilities, planting skills will affect the ability of prospective agents to carry out the CFP (Cahyat et al., 2007). Variation of characteristics require different approaches, mentoring, and counseling. It is expected that by understandingits characteristics, the risk of moral hazard and adverse selection can be minimized.

Market aspects was not a principal concern. According to the principals, product marketing is not their responsibilty, so it was not the focus. Market policy is limited to timber pricing (existing policy is only about pricing of timber PP No 6/2007, article 41 paragraph 1). Setting mechanism and dissemination to agents has not been discussed yet, although aspects to the market is one factor that can increase the interest in planting timber and affects the ability of agents to repay the RFL CFP.

\section{- Farmersperception toward the RFL CFP Scheme}

Perceptions of farmers was assessed based on the content of Minister of Forestry Regulation No. P.09/Menhut-II/2008 and head of the PSA CFDF regulation P01/CFDF-1/2008. The results are: (1) A prospective agent had never heard any information related to the RFL CFP, so they do not understand the requirements and procedures of obtaining the RFL CFP (Riau 89\%, South Kalimantan 100\%, West Java $100 \%$ ); (2) A prospective agent could only manage an area of maximum 2 ha of the minimum requirements of 8 ha (Riau $63 \%$, South Kalimantan 93\%, and West Java 93\%); and (3) Potential agent does not know how to apply for a loan to the formal financial institutions (Riau 71\%, South Kalimantan $71 \%$, and West Java $41 \%$.

The availability of the RFL CFP Fund not automatically increase the interest of farmers to borrow, because the RFL CFP is incompatible with the existing credit system applied in their villages, which is: (1) Most of lenders are from the same village (Riau 57\%, South Kalimantan 59\%), and the lender distance is less than $1 \mathrm{~km}$ (Riau 78\%, South Kalimantan 58\%), and (2) the loan amount is small (in Riau $87 \%$ farmers borrowing $<\operatorname{Rp~500,000,~and~43\% ~from~} 87 \%$ borrowing $<\mathrm{Rp} \mathrm{100,000),} \mathrm{while} \mathrm{in}$ South Kalimantan 45\% ( $\leq$ Rp 500,000) and 22\% (Rp 500,000 - Rp 1,000,000).

The above facts indicate that the principal location in Jakarta would restrain the farmers as prospective agent to access the RFL CFP and the difference amount of RFL CFP with their old local loan potentially caused problems, such as: (1) high transaction cost due to high travel expenses to Jakarta, (2) Moral hazard, especially if the RFL CFP funds are used by agents for cost of consumption (the RFL CFP minimum is Rp 68,255,200 per one IUPHHK (business licence of timber utilization), and (3) Not all 
of the farmers are interested in borrowing in large amount of money since they believe that it would be a sin if they can not return the money. Hence, the beneficiaries of the RFL CFP are commonly rich farmers and investors, while the farmers who are not bankable remain marginalized (adverse selection).

Conditions mentioned above indicate that: (1) there are differences in perception between agent and principal, (2) information owned by the principal and the agent is not symmetric (asymmetric information), and (3) the capacity of principals and agents is imbalance. The differences on perceptions will affect the involvement of parties; information that is not symmetric is often used by either party to perform moral hazard; and the difference of capacity will constrain the implementation and achievement of planned target.

\section{Perceptions of parties (excluding farmers) towards the RFL CFP Scheme}

Perceptions of parties (excluding farmers) towards the RFL CFP Scheme can be summarized as follows:

1. Companies managing timber plantations in Riau, South Kalimantan and West Java: (1) They are not interested in being a partner or the CFP developers; (2) They believe that the CFP will fail if the spatial structure is not corrected and (3) overlapping in the regulations, (4) rights and obligations of the communities must be reaffirmed, (5) the capacity of communities in cultivation, maintenance, and harvesting is still low, and (6) the financial institution that manages funds of the RFL CFP must have sufficient capacity.

2. BPDAS (MoF units in provincial level): the RFL CFP is important, but this is not the only input; other production inputs are also important. The problems, according to BPDAS, are: (1) no aasurance of land right, (2) lack of coaching and mentoring, (3) complex timber administration (TUK), and (4) no guarantee of market.

3. Dinas Kehutanan (forestry service at the district and provincial levels): (1) the RFL CFP procedures are complex and difficult to implement, (2) the RFL CFP is not appropriate for farmers, (3) the commitment of the parties is still lacking, (4) simplify the TUK, and (5) there is no market guarantee,

4. Academicians and researchers: (1) the RFL CFP rules are too complicated, (2) the capacity of farmers is low, (3) need a market guarantee, (4) local government commitment must be increased, and (5) timber business is not prospective.

5. BPD dan BRI (formal financial institutions): (1) RFL CFP Regulations should provide business assurance to farmers, (2) financial management capacity is low, (3) credits of forest plantation are not attractive due to the long payback time and big risk, and, (4) the licensing of the RFL CFP should not lead to high transaction costs.

From the statement smentioned above, the parties are very supportive to the RFL CFP, but they are pesimistic about the success of the RFL CFP (the RFL CFP may fail 
just like KUK DAS and KUHR), especially if the aspects that could potentially cause problems to the bussiness are not resolved by the principal.

\section{E. Perceptions of agents towards the CDA RAD, and factors that contribute to its success}

There are several aspects which can be taken as lessons for the development of the RFL CFP. Perceptions of agents toward the DSA RAD are as follows: (1) $77 \%$ of the agents agreed that CDA RAD role in supplying capital is very big, (2) 100\% of agents agreed that CDA RAD is very easy, (3) $100 \%$ of agents stated that the requirements of borrowing is very easy, which only require ID Card and Family card, (3) $44 \%$ of agents involved in making the rules of loan (interest, penalties, procedures, requirements), (4) $93 \%$ of agents agreed that credit of CDA RAD is in accordance with their wishes and needs, and (5) $100 \%$ of agents stated that the collateral is not burdensome. Collateral is stipulated at a meeting between principal and agent.

The physical environments that support the development of the RFL CFP are: (1) $89 \%$ of agents stated that they could easily obtain means of production, (2) $52 \%$ of agents stated the distance to the market is near, and (3) $85 \%$ of agents stated means of transport is easy. In terms of accesibility of FGA members to the markets stated that: (1) $68 \%$ of agents stated that transport costs are intermediate, and (2) $48 \%$ of agents said that number of buyer was 1-2 people. The dimensions of business of FGA members: (1) $63 \%$ of agents have one kind of business, (2) $47 \%$ of agents carry on business for $1-10$ years, and (3) $33 \%$ of them for $10-20$ years.

Perception of agents to principal and procedure of the CDA RAD is positive and satisfied $(\geq 90 \%)$. The positive perceptions cannot be separated from the rules and guidelines that accomodated their social capital. Participation in making loan requirement and procedures, including refund and sanction within the group has increased the commitment and participation of agents. FGA at the village level appointed as a principal, has low transaction costs, moral hazard, and adverse selection.

The existence of rights and obligations of the Ministry of Agriculture and local governments, along with the rules and guidelines that can be adapted to the conditions of each region has increased the commitment of local government. The commitment is realized through an intensive mentoring in the early establisment by the extension officers and administrators of the FGA, while local governments, subdistrict, and village heads assist in monitoring. The involvement of the parties outside the principal and agent did not increase the transaction cost.

The physical environment also support the agency business, such as easy access to the production means and short distance to the market. Unfavorabee aspects of the physical environment, have ease the agent to sell directly to the market. However, the agents may also sell their products through the principal, and they would help marketing farmers' products in exchange which are approved by both parties. 


\section{CONCLUSION}

The process of formulating regulations and decisions on RFL CFP is top down, and influenced by political situation. The requirements and procedures of the RFL CFP are made in haste, complex, and only offer a single funding scheme. Variation in characteristics and perceptions of farmers have not been accomodated in the RFL CFP rules. It has implications on the low chance of farmers, as prospective agent, to obtain the RFL CFP. PSA CFDF-as principal-is just located in Jakarta. In fact, it has an implication on high of transaction costs, moral hazard and adverse selection. The institution of RFL CFP has been unable to overcome the risk commonly found on the agency relationship. Instead of the Institutional of CDA RAD has to accomodate variations on characteristics and perceptions of the parties, it has been designed to cope with rapid changes in society. It has also been able to increase the commitment of the parties and reduce the risk of moral hazard, adverse selection and high transaction costs.

\section{REFERENCES}

Bungin, B. 2007. Analisis Data Penelitian Kualitatif. Pemahaman Filosofis dan Metodologis ke Arah Penguasaan Model Aplikasi. PT Raja Grafindo Persada, Jakarta.

Cahyat, A., C. Gonner and M. Haug. 2007. Mengkaji Kemiskinan dan Kesejabteraan Rumah Tangga: Sebuab Panduan dengan Contoh dari Kutai Barat. CIFOR. Bogor, Indonesia.

Departemen Kehutanan [Dephut]. 2005. Laporan evaluasi kredit, kredit usaba butan rakyat, Kredit Usaha Persuteraan Alam (KUPA), Kredit Usaha Tani Konservasi Daerah Aliran Sungai (KUK-DAS). Direktorat Jenderal Rehabilitasi Lahan dan Perhutanan Sosial, Departemen Kehutanan, Jakarta.

Eisenhardt, K.M. 1989. Agency theory: an assesment and review. The Academy of Management Review 14(1): 57-74.

Gibbon, R. 2005. Incentives between firms (and within). Management Science 51(1): 217.

Hirakuri, S.R. 2003. Can law save the forest? Lessons from Finland and Brazil. CIFOR. Bogor, Indonesia.

Institute of Development Studies [IDS]. 2006. Understanding Policy Process. A Review of IDS Reseach on the Environment. University of Sussex, United Kingdom.

Jensen, M.C. and W.H. Meckling. 1986. Theory of the firm: managerial behavior, agency costs, and ownership structure. In: Barney, J.B. and W.G. Ouchi (Eds.). Organizational Economics. Jossey Bass Inc., CaliforniaPp. 214-275. 
Kartodihardjo, H. 2008. Diskursus dan aktor dalam pembuatan dan implementasi kebijakan kehutanan: Masalah kerangka pendekatan rasional. Jurnal Manajemen Hutan Tropika 14(1): 19-27.

Lackey, R.T. 2007. Science, scientists and policy advocacy. Conservation Biology 21(1): 12-17.

Maskin, E.S. 2001. Roy Radner and incentive theory. Review of Economic Design 6: 311-324.

Prihadi, N. 2010. Kelembagaan Kemitraan Industri Pengolahan Kayu Bersama Rakyat dalam Rangka Pembangunan Hutan di Pulau Jawa. Disertasi Fakultas Pascasarjana, Institut Pertanian Bogor (unpublished).

Prihadi, N. and B. Nugroho. 2007. Filosofi kontrak kemitraan: kasus kemitraan pengelolaan hutan tanaman dengan masyarakat di Indonesia. Info Pustanling 9(1): 812.

Saaty, T.L. 1993. Pengambilan keputusan bagi para pemimpin: proses hirarki analitik untuk pengambilan keputusan dalam situasi yang kompleks. Setiono, L. (translator), Peniwati, K (editor). PT. Pustaka Binaman Pressindo, Jakarta. Original title: Decision Making for Leaders: the Analitical Hierarchy Process for Decisions in Complex World. 